\title{
Serological Tests for Acquired Syphilis in Immuno-competent Patients
}

\author{
Zoran GOLUŠIN ${ }^{1,2}$, Marina JOVANOVIĆ ${ }^{1,2}$, Milan MATIĆ ${ }^{1,2}$, \\ Ljuba VUJANOVIĆ ${ }^{1,2}$, Tatjana ROŚ ${ }^{1,2}$, Biljana JEREMIĆ ${ }^{1,2}$ \\ ${ }^{1}$ Faculty of Medicine, University of Novi Sad, Serbia \\ ${ }^{2}$ Clinic of Dermatovenereology Diseases, Clinical Center of Vojvodina, Novi Sad,Serbia \\ *Correspondence: Zoran Golušin, E-mail: zgolusin@eunet.rs
}

UDC 616.972-07

\section{DE GRUYTER OPEN}

\begin{abstract}
Serological tests represent a valuable tool for the diagnosis and monitoring the syphilis treatment. Non-treponemal antibodies are nonspecific to detect the infection, but antibody titers are used to monitor the effects of syphilis treatment. A definitive diagnosis of syphilis is made using treponemal tests, because they detect specific antibodies to the treponemal strains or treponemal fragments, which cause syphilis. These tests may remain reactive for years, sometimes for life, regardless of the therapy outcome. Even after successful treatment, approximately $85 \%$ of patients remain positive for treponemal antibodies for the rest of their lives. However, treponemal tests cannot differentiate past infections from a current infection. Therefore, we use a combination of specific and non-specific tests, the two most frequently used diagnostic algorithms. The traditional algorithm begins with a non-treponemal assay, and if it is positive, the treponemal test is done. A positive treponemal test indicates syphilis. The reverse serology algorithm detects early, primary, and treated syphilis that may be missed with traditional screening. However, non-treponemal test is necessary to detect patients with active syphilis.
\end{abstract}

\section{Key words}

Syphilis; Syphilis Serodiagnosis; Serologic Tests; Treponema pallidum; Algorithms; Immunocompetence; Review

I the absence of microbiological diagnosis, serological antibody tests are the mainstay of laboratory diagnosis for all stages of syphilis other than primary. The diagnosis of syphilis is not simple due to the fact that there is no single serological test to diagnose syphilis or monitor the effects of treatment. Treponema pathogenic for humans has the same antigens and a high degree of concordance of DNA, complicating the interpretation of serological tests in geographic areas with endemic treponematoses. The clinical presentation of acquired syphilis is so varied, that definitive diagnosis is made only by serological testing. Serological tests are divided into two groups: non-treponemal and treponemal tests.

\section{Non-treponemal tests}

Non-specific serological tests detect IgM and IgG antibodies (anticardiolipin antibodies) which react with cardiolipin, lecithin and cholesterol from treponema, but also with the same lipid material from damaged host cells. Therefore, these antibodies are not specific to confirm Treponema pallidum infection, but they indicate a tissue damage caused by the infection. Today, the most commonly used non-treponemal tests are the following:

VDRL (Venereal Disease Research Laboratory) flocculation test. Inactivated serum or cerebrospinal fluid, without a complement, given the blurring ("floc") if it is added an antigen (cardiolipin). Examine under a microscope. 
RPR (Rapid Plasma Reagin) - a variant of VDRL test with colored substances for macroscopic reading. It is used when quick view of a large number of sera is necessary. Both of these tests use cardiolipin, a phospholipid, combined with lecithin and cholesterol, as the active antigen for the detection of antibodies suggestive of syphilis (1).

These tests are done manually. They are not automated, so the interpretation of results is subjective. Non-specific antibodies appear about 6 weeks after the infection $(2,3)$. During the primary stage, these antibodies have low titers $(\leq 1: 4)$ and they are present in $40 \%$ of infected subjects, while in the secondary stage low antibody titers are present in only in $11 \%$ of patients (4). The highest antibody titer is seen in the secondary stages of syphilis, from 1:16 to $1: 256$, and declines thereafter, typically falling to $1: 4$ or ot lower in untreated late-latent infection. The advantage of these tests is that they are quick and cheap. The antibody titers mostly correlate with the disease activity. The results should be reported quantitatively, and as such they are used to monitor disease activity and efficacy of treatment. Therefore it is necessary to determine the antibody titer (quantitative VDRL/ $\mathrm{RPR}$ ) on the day of treatment initiation. After healing, the antibody titers are reduced or completely absent. Quantitative non-treponemal testing can also be used to determine if a patient, who appears to have failed treatment, has been re-infected or is "serofast". Serofast patients fail to fully resolve serologically and perpetually exhibit low non-treponemal titers, whereas re-infected patients have persistently higher antibody titers (5). The VDRL and RPR are equally valid assays, but quantitative results from the two tests cannot be compared directly because RPR titers are commonly slightly higher than VDRL titers.

The limitation of these tests is frequent occurrence of false positive or false negative reactions. False positive reactions may be acute (lasting for 6 months) and chronic (lasting longer than 6 months) and account for $20 \%$ of tests. Acute false positive reactions may be seen in the post-immunization period, after recent myocardial infarction and in many febrile infectious diseases (e.g. malaria, hepatitis, chicken pox, measles, etc.), and possibly during pregnancy. Chronic false positive reactions may be seen in injecting drug users, autoimmune diseases, HIV infection, chronic infections such as leprosy, malignancies, chronic liver disease and older age. Also, false positive reactions are due to connective tissue disorders, and Lyme disease. False negative results are obtained in too early or too late stage of infection, when the antibody titers are low, or in the secondary stage of syphilis, with high antibody titers and there is no agglutination - the so-called prozone phenomenon, which occurs in 1 $2 \%$ of patients, usually in pregnant women and HIV infected patients $(2,6,7,8)$.

Generally, up to $90 \%$ of false-positive reactions have a titer of less than $1: 8$, and reactive non-treponemal tests with titers less than 1:8 and subsequent nonreactive treponemal tests are considered to be biological false-positive reactions (2).

\section{Treponemal tests}

The treponemal tests are used for definitive diagnosis of syphilis because they detect specific antibodies (antiterponemal antibodies) utilizing either whole cells or antigens derived from cells of $T$. pallidum causinge syphilis. Specific tests become reactive before nonspecific, but unlike them, they remain reactive for years, sometimes for life, regardless of therapy outcome. Even after successful therapy, approximately $85 \%$ of patients remain positive for treponemal antibodies - for life (9). However, 15 - 25\% of patients treated during the primary stage revert to being serologically nonreactive after $2-3$ years (10). Therefore, treponemal tests are not used to monitor disease activity, as well as to distinguish active from treated syphilis. The most commonly used specific tests are:

TPHA (Treponema pallidum Hemagglutination Assay) is a hemagglutination test often used in laboratories. It detects the presence of specific antibodies in the serum of patients with sensitized sheep erythrocyte agglutination. The test is easy to perform, quick and cost-effective, but it is automatic and subject to individual variations in interpretation.

TPPA (Treponema pallidum Particle Agglutination Assay) is an agglutination test which utilizes gel particles that are sensitized with T. pallidum antigens. If an antigen/antibody reaction occurs, a smooth mat of agglutinated gel particles is well seen in a microtiter tray; if antibody is not present there is no agglutination. The TPPA test is less expensive and 
less complicated than the FTA-ABS tests. The results are read with the unaided eye. It is one of the most commonly used treponemal tests.

FTA-ABS test (Fluorescent Treponemal Antibody Absorption Test) is a fluorescence test used to detect specific antibodies in serum by indirect immunofluorescence.

FTA-ABS test includes an absorption step to increase specificity by removing antibodies directed to nonpathogenic treponema that occur as part of the normal bacterial flora. The resulting antigen/antibody reaction is visualized. The results are graded based on the intensity of the fluorescence. The test has a high sensitivity. It is manual, expensive, and fluorescence interpretation is complex, requires good training, and it is rarely used routinely. A modification of this test is used for the detection only of IgM antibodies (19S IgM FTA-ABS) in the diagnosis of congenital syphilis, because these antibodies do not cross from the mother to the fetus.

EIA (Enzyme Immunoassay) is an enzyme immunoassay and a representative of a new generation of reliable and rapid tests for the detection of specific $\mathrm{IgG}$ and $\mathrm{IgM}$ antibodies.

It is efficient in testing a large number od specimens. Now, it is widely available and increasingly used for screening. The test is automated, but expensive. EIA tests are very sensitive in the detection of primary and secondary syphilis with the IgM EIA being the first test positive in some instances (11). In suspected primary syphilis a IgM should be requested, since these antibodies can be detected at the end of the second week after infection, while IgG antibodies are detected 4 - 5 weeks after infection.

EIA tests have been shown to be equal to or better than FTA-ABS and TPPA tests in overall sensitivity and specificity and are more useful in HIV coinfected individuals (12). There are several versions of immunoassays, depending on the method of detection, such as chemiluminescent immunoassays (CIA), and microbead immunoassays (MIA). These immunoassays may detect IgG, IgM or both IgG and IgM antibodies, are produced against Treponema pallidum (13).

IgM immunoblot is another sensitive metod to detect congenital syphilis.

TPI test (Treponema pallidum Immobilization
Test) is the most reliable test, but it is difficult to perform and today, in the era of fluorescence, this test is rarely applied. To perform this test, live strain of treponema is required. It is based on the fact that serum or cerebrospinal fluid of affected individuals contains immobilizsed specific antibodies. In contact with the immobilizer, live treponema is immobilized. We should not forget that the specific cause of syphilis is associated with movement, and not just a single appearance.

Treponemal assays detect primary infection at a slightly earlier stage than non-treponemal assays (14). Approximately 4 weeks after infection, TPHA and FTA-ABS tests become reactive, and TPI is the last to become positive, even months later.

Before the appearance of chancre and in the first 5 to 15 days, all tests (treponemal and non-treponemal) are negative. Specific tests are rarely false positive, and the reasons may be: HIV infection, bacterial infections, autoimmune disorders, hypergammaglobulinemia and pregnancy $(2,15)$. In more and more countries, point-of-care (POC) rapid diagnostic tests are available for the detection of antitreponemal antibodies (16). They are used for testing certain populations with high prevalence, where immediate diagnosis and treatment is the overriding concern due to a likely lack of followup care. Their advantage and significance may be in the strategy for global elimination of congenital syphilis and mother-to-child-transmission of both syphilis and HIV, because they permit screening and treatment at the same visit, at field level or peripheral clinics remote from laboratories (8).

\section{Serological diagnostic criteria for syphilis}

In screening, if only treponemal serological tests are used, they identify persons with previous successful treatment of syphilis, as well as persons with untreated syphilis. Treponemal tests cannot differentiate earlier infection from current infection. Therefore, a combination of specific and non-specific tests is recommended. If the screening starts with a specific serological test (e.g. EIA), then it is necessary to do a new specific test to confirm (e.g. TPHA) the diagnosis of syphilis. If both tests are positive, then a quantitative non-specific test is necessary (VDRL or RPR) (6).

If the confirmatory treponemal test is positive and non-treponemal test is negative, in patients with 
suspicion of early syphilis, an EIA-IgM test may be used (8). However, the development of $\operatorname{IgM}$ and its persistence after the early latent stage of syphilis is not well understood. Further research is needed before IgM assays can be recommended for routine use in adult testing (17).

If the screening starts with an unspecific serological test, then its positive quantitative findings need to be confirmed by a specific test. If the primary screening consists of both nonspecific and specific tests, it is necessary to quantify the titer of the nonspecific test, especially if the -specific test is positive (14). A finding of a non-specific test (VDRL or RPR) with a titer greater than 1:16, and/or IgM positive test, generally indicates active syphilis and it has to be treated, although serology must be interpreted in the light of the treatment history and clinical findings. The VDRL/RPR and EIA-IgM are often negative in late syphilis, but this does not exclude the need for treatment (15).

\section{Traditional diagnostic algorithm}

The traditional diagnostic algorithm begins with a non-specific test (VDRL or RPR). If it is positive, a specific test is also necessary (Figure 1). In the past, and in many countries today, the most frequently used specific tests are TPHA or TPPA. Thus, all the tests in this algorithm are manual tests, which is justified for economic reasons. This algorithm is cost-effective for small diagnostic laboratories and hospitals. The results of VDRL or RPR screening may correlate more with the disease activity than the results of the reverse algorithm (18).

However, the traditional algorithm has significant limitations, including the use of a screening assay that lacks specificity, requires manual operation, and is subjective (19).

This algorithm does not reveal all subjects with syphilis, which is seen in a study conducted in four laboratories in New York in 2005 and 2006. A total of 116.822 results were reviewed, of which 6.587 (6\%) were reactive to a treponemal screening test (EIA). Among the 6.587 EIA-reactive samples, 3.664 (56.7\%) were found to be nonreactive by RPR. Of the 3.664 discordant sera, a subset (2.512) were tested by TPPA or FTA, of which 433 (17.2\%) were nonreactive, suggesting false-positive EIA screening results (20). The conclusion of this study was that

\section{NON-TREPONEMAL TEST}
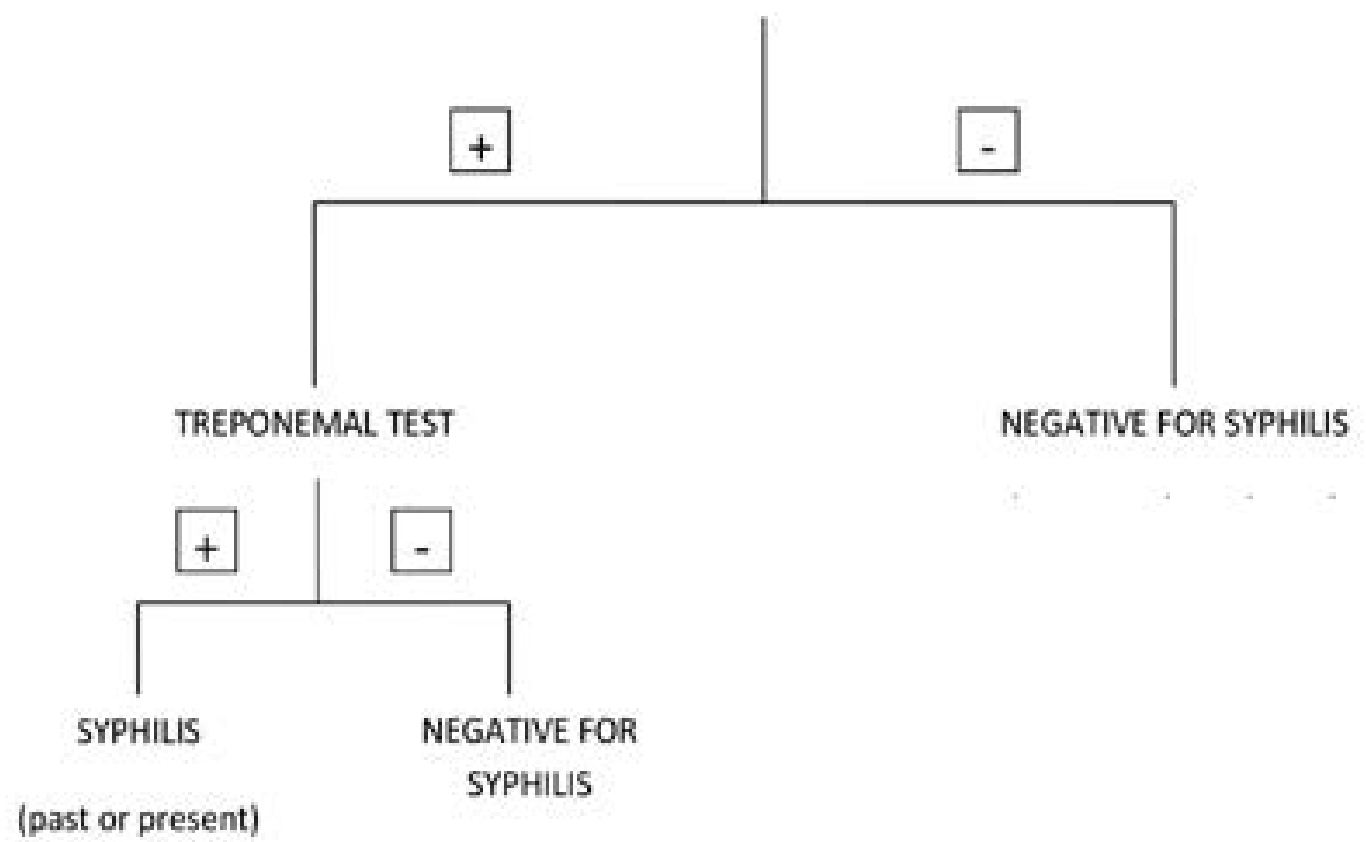

Figure 1. Traditional syphilis serology testing algorithm 
3.664 patients identified by screening, would not have been detected by the traditional algorithm.

In another study, among 24.124 tested samples, there were 2.756 reactive to TPPA. The results of nontreponemal tests in these patients showed that 667 of 2.756 (24.2\%) samples were RPR nonreactive (21).

For subjects at a certain stage of the disease the traditional algorithm does not provide diagnostic reliability.

The traditional algorithm, approach could be missing some untreated cases, especially patients at the late latent stage of the disease where seroreactivity to non-treponemal tests declines (1).

Across different studies and demographic populations (including HIV patients), up to $40 \%$ of untreated late latent cases were found to be nonreactive to non-treponemal assays. The potential for false-negative results in early primary syphilis or in late latent syphilis may be greater when using a nontreponemal assay for initial screening (7).

Using the clinical diagnostic results as the gold standard, the sensitivity of the traditional algorithm was only $75.81 \%$. The negative likelihood ratio was $0.24(>0.1)$, indicating a high probability of falsenegative results (21).

\section{Reverse diagnostic algorithm}

The increasing availability of commercial and automated treponemal tests, as well as the shortcomings observed in the traditional algorithm, imposed the need for creating a new diagnostic algorithm.

The reverse diagnostic algorithm starts with modern treponemal tests, and then it is followed by a non-treponemal test (Figure 2). In reverse diagnostic algorithm, sera are examined with automated methods (e.g. EIA) that can be linked to the information system in the laboratory, which reduces the possibility of errors when manually entering results. The new algorithm increases the number of people detected in the primary stage and in late syphilis, because in these stages of the disease treponemal tests have greater sensitivity and specificity than non-treponemal tests. The disadvantages of the new diagnostic algorithm are: EIA cannot differentiate an active disease from a case with cured syphilis (which in practice leads to unnecessary re-treatment), the results show more false-positives results than the traditional algorithm, the traditional algorithm tests (VDRL/RPR) are easier to perform, cheaper, do not require expensive laboratory equipment and a large number of samples (rapid screening) can be examined in a short time (19).

In order to avoid discrepancies, it is recommended that sera testing reactive by EIA, but nonreactive by RPR, should be tested by another treponemal test (TPPA), which serves as confirmatory treponemal assay, which is particularly important in a population with a low prevalence in order to avoid false positive diagnosis of syphilis (22).

Treponemal evaluation tests, used in reverse algorithm, are automated immunoassays and the microplate enzyme immunoassays are suitable for first screening, whilst the TPPA particle agglutination is more adaptive to be used as a second, confirmatory treponemal assay (23).

The reverse algorithm still has a high diagnostic significance in early syphilis, as well as in late syphilis in high-prevalence population (with a syphilis rate of $11.40 \%)(21)$.

To improve the diagnosis of the primary stage syphilis, we should expect more frequent use of realtime PCR for the detection of T. pallidum.

The PCR assay demonstrated a sensitivity and specificity of $87.0 \%$ and $93.1 \%$, respectively, compared to dark-field microscopy in patients with suspected primary syphilis. However, the PCR assay showed only $43.0 \%$ sensitivity in patients with suspected secondary syphilis, so its application after the primary stage of syphilis would not have advantages over the standard serological methods (24). The next step in improving the diagnosis of syphilis will be introduction of POC tests, that can accurately identify and differentiate patients with treated versus untreated syphilis. A promising POC device described by Castro et al. uses immunofiltration to detect and differentiate treponemal and nontreponemal antibodies in the same test. Results are available in $2-$ $10 \mathrm{~min}$, with reported sensitivities and specificities of at least 96.0 and $97.0 \%$, respectively (25).

\section{Monitoring the effects of treatment}

The monitoring of the effects of syphilis treatment includes identification of the titer by a non-specific test on the first day of treatment, to provide a baseline for measuring a decrease in antibody titers. Sera 


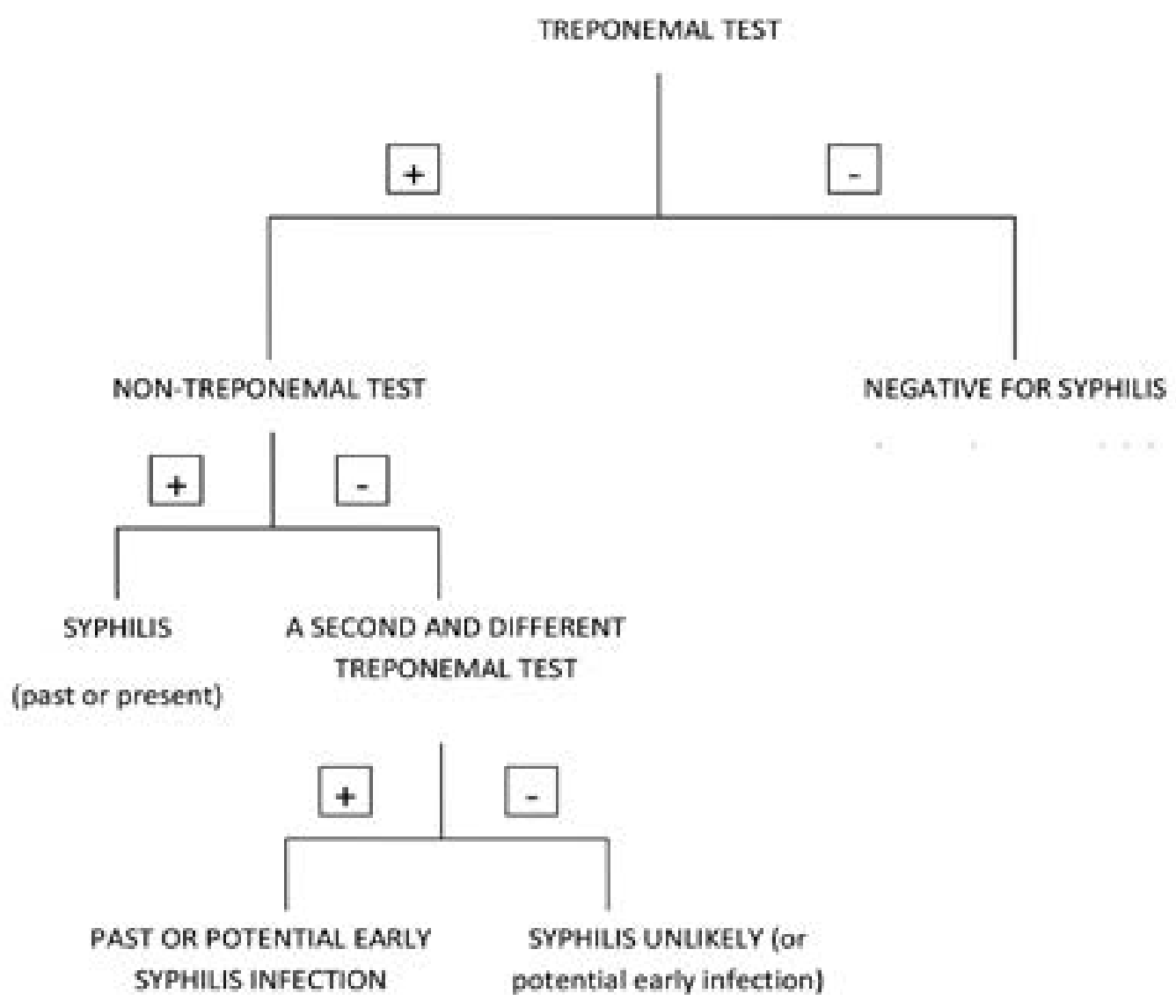

Figure 2. Reverse syphilis serology testing algorthm

should be obtained at 1 month, 3 months and every 6 months subsequently, ideally the identical nontreponema test should be used and all samples tested in the same laboratory. This should be continued until the non-treponemal test becomes negative, attains a low plateau ( $\leq 1: 4$, sustained for 1 year and in the absence of ongoing risk) (8).

Adequate treatment is demonstrated by a 4 -fold drop in titer by non-treponemal assay within 3 to 6 months. However, the serologic response following successful treatment of syphilis infection remains unclear. Some individuals may have increasing titers or be serofast, where appropriate treatment causes little or no change in titer (18).

Typically, the non-treponemal antibody titer declines by a 4-fold after three months (eg, from 1:32 to $1: 8$ ) and by 8 -fold after six months (eg, from 1:32 to $1: 4)$ with standard therapy. The time for decline in antibody titer may be longer with the RPR test than with the VDRL test (26). However, there is evidence that $15 \%$ of treated patients with early syphilis will not show a 4-fold decline in titer at one year posttreatment (27).

After successful treatment, the RPR and VDRL tests usually become nonreactive after one year in patients with primary syphilis, after two years in patients with secondary syphilis, and after five years in latent syphilis (28).

Some experts define treatment failure as a 4-fold or greater increase in the non-treponemal test titer or a recurrence of signs or symptoms (29).

Some authors also consider the persistence of RPR/VDRL titers at or over 1:64 as a serologic treatment failure (30). 


\section{Interpretation of serological tests in cerebrospinal fluid for neurosyphilis}

Neurosyphilis cannot be diagnosed serologically, and diagnosis must be based on the clinical judgment. Cerebrospinal fluid (CSF) assessment is not indicated in early syphilis (HIV positive or negative), unless there are neurological, ocular or auricular symptoms. Indications for cerebrospinal fluid testing are: clinical evidence of neurological, ocular and auricular involvement, regardless of the stage of the disease, and in tertiary syphilis (cardiovascular, gummatous). Although robust data are lacking, CSF control may be indicated also in asymptomatic patients in the following situations for exclusion of asymptomatic neurosyphilis: in HIV positive patients with late syphilis and CD4+ cells $\leq 350 / \mathrm{mm}^{3}$ and/or a serum VDRL/RPR titer $\geq 1: 32$; in case of serological failure; in case of use of alternative treatment (tetracyclines) during late syphilis (8).

Accurate interpretation of serological findings means that the CSF must not be macroscopically contaminated with blood. In the majority of patients with symptomatic neurosyphilis more than 5 leukocytes $/ \mathrm{mm}^{3}$ are found. The level of proteins may not be elevated in neurosyphilis. It is always necessary to quantitatively determine the positivity of serological tests in CSF.

The sensitivity of VDRL/RPR test in the CSF ranges from $10 \%$ in asymptomatic patients, and $90 \%$ in symptomatic patients, which means that a negative VDRL/RPR test does not rule out neurosyphilis (31). A negative treponemal test (TPPA/TPHA) on CSF excludes neurosyphilis, and a positive test is highly sensitive for neurosyphilis but lacks specificity, because the reactivity may be caused by transudation of immunoglobulins from the serum into the CSF or by leakage through a damaged blood brain barrier resulting from conditions other than syphilis. Because of that, positive CSF TPHA/TPPA does not confirm the diagnosis of neurosyphilis.

Neurosyphilis is unlikely when the CSF TPHA titer is $<320$ or the TPPA titer $<640$ (15).

Establishing the so-called TPHA index (CSF TPHA/albumin quotient [CSF albumin x109/serum albumin]) can help establishing the final diagnosis. A TPHA index $>70$ and a CSF TPHA titer $>320$ are the most reliable in supporting the diagnosis of neurosyphilis, but unfortunately determination of the TPHA index is not widely available (32). In case of an abnormal CSF examination (high protein level and/or hypercytosis), repeat CSF examination must be performed after treatment (6 weeks to 6 months) (8).

\section{Diagnosis of cardiovascular syphilis}

Every patient with aortic insufficiency or thoracic aortic aneurysm should be screened for syphilis (8). Positive serologic tests combined with typical clinical changes found in cardiovascular syphilis are indispensable diagnostic indicators of cardiovascular syphilis. Patients with suspected cardiovascular syphilis need to be assessed by a cardiologist.

\section{Conclusion}

Given that each algorithm for serological diagnosis of syphilis has some minor or major deficiencies, rapid tests based on PCR technology should be developed. They should aid in differentiation of untreated from treated syphilis, and improve diagnosis to distinguish specific and non-specific antibodies in a single assay.

\section{Abbreviations}

VDRL - Venereal Disease Research Laboratory

RPR - Rapid Plasma Reagin

HIV - Human Immunodeficiency Virus

TPHA - Treponema pallidum Hemagglutination

Assay

TPPA - Treponema pallidum Particle Agglutination Assay

FTA-ABS test - Fluorescent Treponemal Antibody Absorption Test

EIA - Enzyme Immunoassay

TPI - Treponema pallidum Immobilization

POC - Point-of-Care

PCR - Polymerase Chain Reaction

CSF - Cerebrospinal fluid

\section{References}

1. Larsen SA, Steiner BM, Rudolph AH. Laboratory diagnosis and interpretation of tests for syphilis. Clin Microbiol Rev. 1995;8(1):1-21.

2. Stary A, Stary G. Sexually transmitted infections. In: Bolognia JL, Jorizzo JL, Schaffer JV. Dermatology. $3^{\text {rd }}$ ed. Philadelphia: Elsevier; 2012. p. 1367-89. 
3. Ratnam S. The laboratory diagnosis of syphilis. Can J Infect Dis Med Microbiol. 2005;16(1):45-51.

4. Ray K, Lahta R, Sachdeva KG, Ganguly DD, Bhargava NC. Screening and confirmation of syphilis by serology - a five year experience. Indian J Sex Transm Dis. 1991;12:47-50.

5. Workowski KA, Berman S, Centers for Disease Control and Prevention (CDC). Sexually transmitted diseases treatment guidelines, 2010. MMWR Recomm Rep. 2010;59(RR12):1-110.

6. Geusau A, Kittler H, Hein U, Dangl-Erlach E, Stingl G, Tschachler E. Biological false-positive tests comprise a high proportion of venereal disease research laboratory reactions in an analysis of 300,000 sera. Int J STD AIDS. 2005;16(11):722-6.

7. Soreng K, Levy R, Fakile Y. Serologic testing for syphilis: benefits and challenges of a reverse algorithm. Clinical Microbiology Newsletter. 2014;36(24):195-202.

8. Janier M, Hegyi V, Dupin N, Unemo M, Tiplica GS, Potočnik M, et al. 2014 European guideline on the management of syphilis. J Eur Acad Dermatol Venereol. 2014;28(12):1581-93.

9. Lewis DA, Lukehart SA. Antimicrobial resistance in Neisseria gonorrhoeae and Treponema pallidum: evolution, therapeutic challenges and the need to strengthen global surveillance. Sex Transm Infect. 2011;87 Suppl 2:ii39-43.

10.Romanowski B, Sutherland R, Fick GH, Mooney D, Love EJ. Serologic response to treatment of infectious syphilis. Ann Intern Med. 1991;114(12):1005-9.

11. Bosshard PP. Usefulness of IgM-specific enzyme immunoassays for serodiagnosis of syphilis: comparative evaluation of three different assays. J Infect. 2013;67(1):35-42.

12. Gutierrez J, Vergara MJ, Soto MJ, Piedrola G, Maroto Md. Clinical utility of a competitive ELISA to detect antibodies against Treponema pallidum. J Clin Lab Anal. 2000;14(2):83-6.

13.Sena AC, White BL, Sparling PF. Novel Treponema pallidum serologic tests: a paradigm shift in syphilis screening for the 21st century. Clin Infect Dis. 2010;51(6):700-8.

14. Hagedorn HJ. Laboratory diagnosis of syphilis. In: Gross G, Tyring SK, editors. Sexually transmitted infections and sexually transmitted diseases. Berlin: Springer-Verlag; 2011. p. 143-50.

15.Kingston M, French P, Goh B, Goold P, Higgins S, Sukthankar A, et al. UK National Guidelines on the Management of Syphilis 2008. Int J STD AIDS. 2008;19(11):729-40.

16. Tucker JD, Bu J, Brown LB, Yin YP, Chen XS, Cohen MS. Accelerating worldwide syphilis screening through rapid testing: a systematic review. Lancet Infect Dis. 2010;10(6):381-6.

17.Zanto SN. Changing algorithms in syphilis laboratory diagnosis. Clinical Microbiology Newsletter. 2010;32(8):59-64.

18. Owusu-Edusei KJr, Peterman TA, Ballard RC. Serologic testing for syphilis in the United States: a cost-effectiveness analysis of two screening algorithms. Sex Transm Dis. 2011;38(1):1-7.

19. Binnicker MJ. Which algorithm should be used to screen for syphilis? Curr Opin Infect Dis. 2012;25(1):79-85.

20.Centers for Disease Control and Prevention (CDC). Syphilis testing algorithms using treponemal tests for initial screening: four laboratories, New York City, 2005-2006. MMWR Morb Mortal Wkly Rep. 2008;57(32):872-5.

21.Tong ML, Lin LR, Liu LL, Zhang HL, Huang SJ, Chen YY, et al. Analysis of 3 algorithms for syphilis serodiagnosis and implications for clinical management. Clin Infect Dis. 2014;58(8):1116-24.

22. Jost H, Castro A, Cox D, Fakile Y, Kikkert S, Tun Y, et al. A comparison of the analytical level of agreement of nine treponemal assays for syphilis and possible implications for screening algorithms. BMJ Open. 2013;3(9):e003347.

23.Malm K, Andersson S, Fredlund H, Norrgren H, Biague A, Mansson F, et al. Analytical evaluation of nine serological assays for diagnosis of syphilis. J Eur Acad Dermatol Venereol. 2015;29(12):2369-76.

24.Gayet-Ageron A, Ninet B, Toutous-Trellu L, Lautenschlager S, Furrer H, Piguet V, et al. Assessment of a real-time PCR test to diagnose syphilis from diverse biological samples. Sex Transm Infect. 2009;85(4):264-9.

25. Castro AR, Mody HC, Parab SY, Patel MT, Kikkert SE, Park $\mathrm{MM}$, et al. An immunofiltration device for the simultaneous detection of non-treponemal and treponemal antibodies in patients with syphilis. Sex Transm Infect. 2010;86(7):532-6.

26.Brown ST, Zaidi A, Larsen SA, Reynolds GH. Serological response to syphilis treatment. A new analysis of old data. JAMA. 1985;253(9):1296-9.

27.Sexually transmitted diseases treatment guidelines 2002. Centers for Disease Control and Prevention. MMWR Recomm Rep. 2002;51(RR-6):1-78.

28. Wicher K, Horowitz HW, Wicher V. Laboratory methods of diagnosis of syphilis for the beginning of the third millennium. Microbes Infect. 1999;1(12):1035-49.

29.Farhi D, Dupin N. Origins of syphilis and management in the immunocompetent patient: facts and controversies. Clin Dermatol. 2010;28(5):533-8.

30.Smith NH, Musher DM, Huang DB, Rodriguez PS, Dowell ME, Ace W, et al. Response of HIV-infected patients with asymptomatic syphilis to intensive intramuscular therapy with ceftriaxone or procaine penicillin. Int J STD AIDS. 2004;15(5):328-32.

31.Larsen SA, Hambie EA, Wobig GH, Kennedy EJ. Cerebrospinal serologic test for syphilis: treponemal and nontreponemal tests. In: Morisett R, Kurstak E, editors. Advances in sexually transmitted diseases. Utrecht: VNU Science Press; 1985. p. 157-62.

32.Luger AF, Schmidt BL, Kaulich M. Significance of laboratory findings for the diagnosis of neurosyphilis. Int J STD AIDS. 2000;11(4):224-34. 


\section{Pregled seroloških testova na stečeni sifilis kod imunokom- petentnih osoba}

\section{Sažetak}

U nedostatku rutinske mikrobiološke dijagnoze, serološki testovi predstavljaju osnovu laboratorijske dijagnostike sifilisa. Nespecifični (netreponemski) testovi se rade manuelno, odnosno nisu automatizovani, pa je interpertacija rezultata subjektivna. Nespecifična antitela javljaju se tokom primarnog stadijuma sifilisa u niskom titru ( $\leq 1: 4)$ kod 40\% obolelih, dok je u sekundarnom stadijumu kod samo $11 \%$ obolelih prisutan nizak titar nespecifičnih antitela. Specifični (treponemski) testovi postaju reaktivni pre nespecifičnih, ali za razliku od njih ostaju reaktivni godinama, nekad i doživotno, bez obzira na adekvatnu terapiju.

Ukoliko bismo u skriningu koristili samo specifične testove, ne bismo mogli da razlikujemo osobe sa nelečenim sifilisom od osoba sa uspešno lečenim sifilisom. Takođe, specifični testovi ne mogu da razlikuju nekadašnju infekciju od aktuelne infekcije. Zbog toga koristimo kombinaciju specifičnih i nespecifičnih testova.

Tradicionalni dijagnostički algoritam započinjemo nespecifičnim testom (VDRL ili RPR). Ukoliko je on pozitivan, radimo specifičan test (najčešće
TPHA ili TPPA). Svi testovi u ovom algoritmu su manuelni testovi što ima opravdanja iz ekonomskih razloga. Međutim zbog određenih manjakovosti ovog algoritma, predložen je reverzni algoritam u kojem se serumi prvo pregledaju automatizovanim metodama (na primer EIA). Preporuka je da se serumi koji su EIA reaktivni, a RPR nereaktivni, testiraju pomoću još jednog treponemskog testa (na primer TPPA) koji služi kao potvrdni, što je naročito bitno u populaciji sa niskom prevalencijom sifilisa kako bi se izbegla lažno pozitivna dijagnoza.

Da bismo pratili efekte lečenja sifilisa, moramo imati titar nespecifičnog testa određen prvog dana lečenja, pre započinjanja terapije. Uspešno sprovedenom terapijom smatra se četvorostruki pad titra nespecifičnih antitela, tri do šest meseci po završetku terapije.

$S$ obzirom na to da svaki algoritam za serološku dijagnostiku sifilisa ima određene manje ili veće nedostatke, treba očekivati razvoj brzih testova baziranih na PCR tehnologiji koji bi mogli da razlikuju lečeni od nelečenog sifilisa, kao i unapređenje dijagnostike koja bi razlikovala specifična od nespecifičnih antitela u jednom testu.

\section{Ključne reči:}

Sifilis; Serološka dijagnoza sifilisa; Serološki testovi; Treponema pallidum; Algoritmi; Imunokompetencija; Pregled 